\title{
Implementation of Curriculum Planning on Inclusive Physical Education in Primary Schools in Hong Kong 香港小學融合體育教學的設計
}

\author{
Chunxiao LI Shihui CHEN \\ Department of Health and Physical Education, \\ Hong Kong Institute of Education, HONG KONG
}

李春曉 陳適喗
香港教育學院健康與體育學系

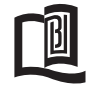

\begin{abstract}
The purpose of this study was to examine how regular primary school PE teachers planning their inclusive physical education in Hong Kong. The questionnaires (IPESDQ) and cover letters with instructions for completing the questionnaire were delivered to 115 physical educators. A follow-up was made to contact nonrespondents two weeks and the final return rate of the survey was at $72.2 \%(\mathrm{n}=83)$. Results showed most teachers $(49.4 \%)$ used the curriculum guidance draft by themselves; only $10.4 \%$ of teachers used individualized education plan (IEP), the most common teaching object (74.0\%) was for understanding and enjoying exercise and sports; basketball, track and field, football, game, rope skipping, volleyball, badminton, and gymnastics were popularly used for teaching; Direct instruction strategy was popularly used by $72.7 \%$ of teachers and only $7.8 \%$ of teachers used inquiry teaching for inclusive physical education; Most teachers used sport skills (94.8\%), attitude $(92.2 \%)$ as evaluation contents. Perspectives for developing inclusive physical education service delivery were provided at last.
\end{abstract}

Keywords: physical education, special needs population, teaching

\section{摘要}

本研究採用修訂後的《融合體育教學》問卷, 對小學體育教師進行了調查, 目的在了小學體育教師如何規劃融合體育教學。 83位教師回應了此次調查, 經過統計後發現, $49.4 \%$ 的教師使用自己制定的課程綱要設計融合體育教學, 僅有 $10.4 \%$ 的教師採用個 別化教學計劃（IEP）; 教師普遍以瞭解和享受體育運動作為課堂教學目標 $(74.0 \%)$; 籃球, 田徑, 足球, 遊戲, 跳繩, 排球, 羽毛球, 體操等教學內容受到教師的青睞; $72.7 \%$ 的教師採用直接教學法, 僅有 $7.8 \%$ 的教師使用探究式教學法 ; 多數教師將運動 技能 $(94.8 \%)$ ，和態度 $(92.2 \%)$ 作為評價學生學習的內容。

關鍵字: 體育, 特殊需要學生, 教學

\section{Introduction}

Inclusion is the philosophy of supporting the educational needs of students with disabilities in general education settings (Block, 2007). The inclusion of students of all ability levels into general physical education (GPE) classes can provide an environment where all students are able to receive adequate instruction and substantial physical activity without jeopardizing skills or cognition of classmates (Block, \& Zeman, 1996; Obrusnikova, Valkova, \& Block, 2003; Vogler, Koranda, \& Romance, 2000) and to develop social skills (Block, 2007). The other benefit 
from inclusion of students with disabilities into regular physical education programs is peers without disabilities can develop a positive attitude by nondisabled students (Block, \& Vogler, 1994; Sherrill, Heikinaro-Johansson, \& Slininger, 1994). It also can, however, result in negative experiences such as teasing and social segregation (Chamberlin, 1999; Place, \& Hodge, 2001).

The trend toward increasing inclusion of children with and without disabilities can be observed from many countries (DePauw, \& Doll-Tepper, 2000), for example, approximately $95 \%$ of school-aged individuals with disabilities participate in general physical education classes in U.S. (Sherrill, 2004; U.S. Department of Education, 2005). The Hong Kong government did not take any actions in terms of including students with disabilities in the regular school setting until late 1997 (Chen, Lau, \& Jin, 2006). To date, most students with special education needs are educated in 62 special schools and some students with mild to moderate disabilities are included in regular schools in Hong Kong (Education Bureau of Hong Kong, EDB, 2007). In the past decade, we witnessed that schools, including schools from Hong Kong, were experiencing a growing trend of integrating students with disabilities into the general settings. Thus, physical educators are responsible for teaching students with disabilities in their general physical education classroom.

Examination of the current status of inclusive physical education service delivery (e.g., placement, curriculum content, and activity offerings needs) can be used for developing models that may enhance the likelihood of successful inclusion (Chandler, \& Greene, 1995). Student placement was an area of investigation. A nationwide study on examining placement options on students with disabilities was conducted by Jansma and Decker (1990). Findings showed that the majority of students with disabilities were inclusive in regular settings. The other study about placement variables of inclusive physical education was conducted by Jansma and Decker (1992). Results indicated that variables influence on placement of inclusive physical education included severity of disability, safety considerations, and attainment of instructional objectives, special education teachers' recommendations, teachers' recommendations, parents' opinions and disability type.
Melograno and Loovis (1991) compared the result of comprehensive surveys on status of physical education for students with disabilities between 1980 and 1988 . They found that results in 1980 were reaffirmed in 1988; teachers were lack of the ability to provide appropriate physical education for students with disabilities. Chandler and Greene (1995) also comprehensively examined the current status of inclusive physical education service delivery, but they focused on the placement, teachers' perceived needs, curriculum content, and activity offerings needs.

Lieberman et al. (2002) found that GPE teachers believed they faced many barriers when including students with visual impairments in GPE classes that revolved around lack of preparation. Other barriers to inclusion reported were lack of equipment (63\%), curriculum (57\%), and time in schedule (56\%). More recently, Hodge et al. (2004) found that large classes adversely impacts teachers' teaching effectiveness, teachers' confronted with a lot of challenges (e.g., lack of knowledge, safety of all students, and class management) when delivering inclusive physical education.

While the above findings provide important information for guiding both school districts (e.g., the status of inclusive physical education) and higher education institutions (e.g., physical educators' professional development), they offer little insight into the curriculum planning (i.e., how teachers planning inclusive physical education) by physical educators. Unique to the study conducted by Duchane and French (1998), they investigated the attitudes and grading practices of secondary physical educators in regular physical education. They reported that teachers used a different grading criterion for their students with disabilities compared to their students without disabilities. Students with disabilities were graded mostly on participation, dressing, and effort, while students without disabilities were graded more on written, fitness, and skill tests. 
Collectively, findings through examining the present status of inclusive physical education service delivery can be used for improve service delivery quality and thus to improve students' learning. But there is a literature gap on systematically explore how physical educators' planning their curricular. For example, little information on physical educators' teaching strategies and assessment were provided within previous research findings. Moreover, in Hong Kong, research findings concerning inclusive physical education are very limited (Chen, Lau, \& Jin, 2006). Thus, the purpose of this study was to address how regular school P.E. teachers planning their curriculum and a profile of curriculum planning was expected to be drawn.

\section{Method}

\section{Participants}

The target participants of this study were all P.E. teachers from the general primary schools which include students with disabilities in Hong Kong. A roster of 280 general primary schools which include students with disabilities was obtained from the website of EDB. Generally, there are at least two P.E. teachers from each primary school and they should possess education certificate in order to deliver physical education service. Physical education teachers $(\mathrm{N}=115$, see Table 1) from these general primary schools were selected through two ways, which were "snow ball" and phone calls for getting the permission for administering questionnaires.

Table 1. Demographics of Participants $(\mathrm{N}=83)$.

\begin{tabular}{|c|c|c|c|c|c|c|c|c|}
\hline \multicolumn{2}{|c|}{ Gender } & \multicolumn{4}{|c|}{ Age } & \multicolumn{3}{|c|}{ Teaching Experience } \\
\hline M & F & $21-30$ & $31-40$ & $41-50$ & $>51$ & $1-5$ & $6-10$ & $>10$ \\
\hline 59 & 24 & 46 & 25 & 8 & 4 & 38 & 9 & 20 \\
\hline
\end{tabular}

\section{Instrument}

The data-collection instrument (Inclusive phyA list for administering questionnaires was created after getting the permissions for administering the questionnaire through ways of "snow ball" and phone call. A questionnaire, a postage paid return envelope (not for participants using email) and a cover letter explaining the purpose of the study and instructions for completing the questionnaire were delivered or emailed to each participant. Totally 115 questionnaires were sent to our participants at the first mail-out. 60 questionnaires were collected after first mailout. A follow-up was made to contact nonrespondents two weeks after the initial dissemination of the questionnaires (Porretta, Kozub, \& Lisboa, 2000). After the second round mail-out, another 23 questionnaires were collected. Total 83 questionnaires had been received and the final return rate of the survey was at $72.2 \%$ (see Table 1).

\section{Data Analysis}

Data was analyzed through the software of SPSS 16.0 for Windows. Descriptive statistics (means, frequencies, and percentages) was used to report participants' demographics and how teachers planning their curriculum.

\section{Results}

\section{Curriculum Guidance}

With relevant to Figure 1, most teachers (49.40\%) used curriculum guidance drafted by themselves when planning inclusive physical education. $40.30 \%$ of teachers used general curriculum guidance released by EDB of Hong Kong. Guidance from special schools was seldom used, at $7.80 \%$.

\section{Teaching Plan}

Individualized Education Plan (IEP) was not popularly used for planning teaching in terms of Figure 2. Most teachers, at $46.80 \%$, planned their inclusive physical education with convenience or flexibility. It was disappointed to find that $9.10 \%$ of teachers make no plans for their teaching. 
Figure 1. Percentage of Curriculum Guidance for Delivering Inclusive PE Note. GCG=general curriculum guidance, SSG=special school guidance, GDS=guidance drafted by self, OTH=others.

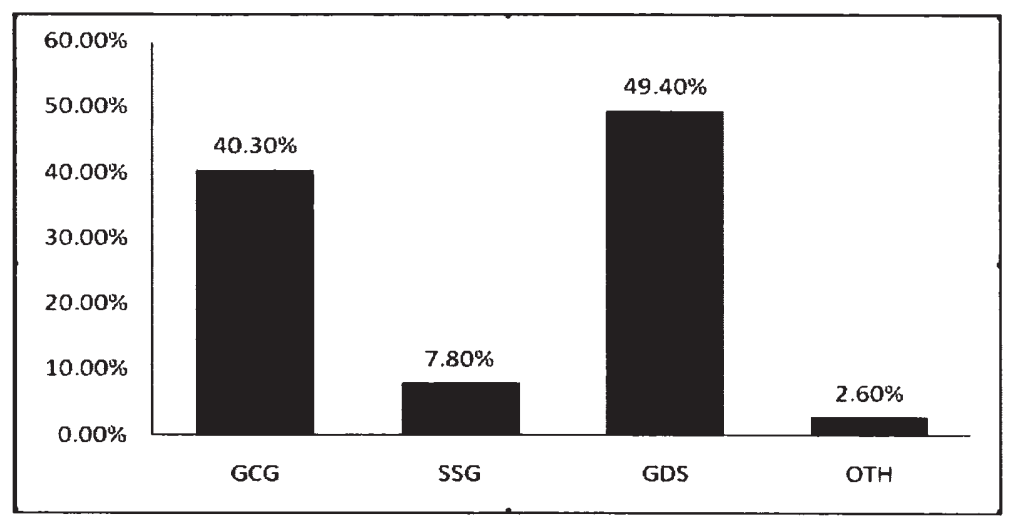

Figure 2. Percentage of How Teachers Planning Inclusive PE Note. IEP= Individualized Education Plan, $\mathrm{CP}=$ convenience planning, $\mathrm{SGPE}=$ same as general physical education, $\mathrm{NP}=$ no planning.

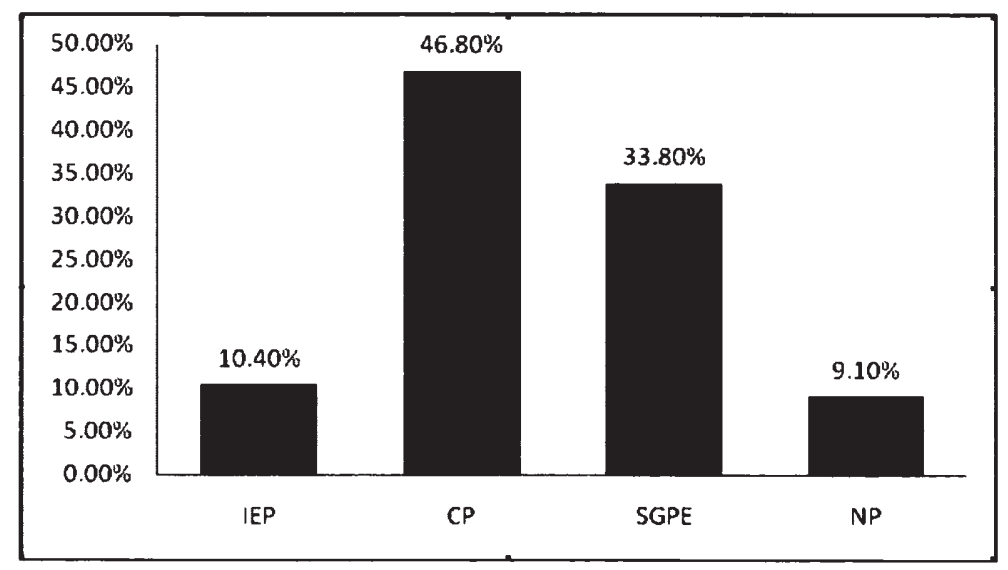

\section{Teaching Objective}

Understand and enjoy exercise and sports was selected as the most common teaching objective (74.0\%) for students with disabilities, followed by cultivate health and lifestyle and exercise habits (64.9\%). 36.4\% of teachers chose overcoming disabilities and improving sport knowledge and skills as their teaching objective (see Table 2).

Table 2. Teaching Objective Frequencies $(\mathrm{N}=83)$.

\begin{tabular}{llll}
\hline \multicolumn{1}{c}{ Teaching Objectives } & \multicolumn{2}{c}{ Responses } & Percent of \\
\cline { 2 - 3 } & $\mathrm{N}$ & Percent & Cases \\
\hline Overcome disability and improve sport knowledge and skills & 23 & $14.6 \%$ & $29.9 \%$ \\
Understand and enjoy exercise and sports & 57 & $36.1 \%$ & $74.0 \%$ \\
Develop self-worth and demonstrate general competency & 28 & $17.7 \%$ & $36.4 \%$ \\
Cultivate health and lifestyle and exercise habits & 50 & $31.6 \%$ & $64.9 \%$ \\
Total & 158 & $100.0 \%$ & $205.2 \%$ \\
\hline
\end{tabular}




\section{Teaching Content}

Table 3 described the frequencies of teaching contents. As shown in the table, basketball, track and field, football, game, rope skipping, volleyball, badminton, and gymnastics were popularly used for teaching. Teaching contents, such as swimming, martial arts, and trampoline were not commonly used for physical education in primary schools. Other teaching contents, such as squash, shuttle cock, and tchoukball were also taught in primary schools according to our research findings.

Table 3. Teaching Content Frequencies (N=83).

\begin{tabular}{llll}
\hline & \multirow{2}{*}{ Teaching Content } & \multicolumn{2}{c}{ Responses } \\
\cline { 2 - 3 } & \multicolumn{2}{c}{$\mathrm{N}$} & \multicolumn{2}{c}{ Percent } & Percent of Cases \\
\hline Track and field & 63 & $12.6 \%$ & $81.8 \%$ \\
Basketball & 68 & $13.6 \%$ & $88.3 \%$ \\
Volleyball & 42 & $8.4 \%$ & $54.5 \%$ \\
Football & 48 & $9.6 \%$ & $62.3 \%$ \\
Handball & 20 & $4.0 \%$ & $26.0 \%$ \\
Table tennis & 26 & $5.2 \%$ & $33.8 \%$ \\
Badminton & 41 & $8.2 \%$ & $53.2 \%$ \\
Dance & 24 & $4.8 \%$ & $31.2 \%$ \\
Gymnastic & 39 & $7.8 \%$ & $50.6 \%$ \\
Swimming & 6 & $1.2 \%$ & $7.8 \%$ \\
Martial arts & 5 & $1.0 \%$ & $6.5 \%$ \\
Rope skipping & 46 & $9.2 \%$ & $59.7 \%$ \\
Dodgeball & 19 & $3.8 \%$ & $24.7 \%$ \\
Trampoline & 1 & $.2 \%$ & $1.3 \%$ \\
Game & 47 & $9.4 \%$ & $61.0 \%$ \\
others & 5 & $1.0 \%$ & $6.5 \%$ \\
Total & 500 & $100.0 \%$ & $649.4 \%$ \\
\hline
\end{tabular}

\section{Teaching Strategy}

Direct instruction strategy was popularly used by $72.7 \%$ of teachers and only $7.8 \%$ of teachers used inquiry teaching for inclusive physical education (see Table 4).
Through Table 4, still, around $40.0 \%$ of responses showed that strategies including individual education, peer teaching, collaborative learning, and games approach were used for inclusive physical education.

Table 4. Teaching Strategy Frequencies $(\mathrm{N}=83)$.

\begin{tabular}{|c|c|c|c|}
\hline \multirow{2}{*}{ Teaching strategy } & \multicolumn{2}{|c|}{ Responses } & \multirow[b]{2}{*}{ Percent of Cases } \\
\hline & $\mathrm{N}$ & Percent & \\
\hline Direct instruction & 56 & $30.3 \%$ & $72.7 \%$ \\
\hline Individual education & 30 & $16.2 \%$ & $39.0 \%$ \\
\hline Peer teaching & 34 & $18.4 \%$ & $44.2 \%$ \\
\hline Collaborative learning & 30 & $16.2 \%$ & $39.0 \%$ \\
\hline Inquiry teaching & 6 & $3.2 \%$ & $7.8 \%$ \\
\hline Games approach & 29 & $15.7 \%$ & $37.7 \%$ \\
\hline Total & 185 & $100.0 \%$ & $240.3 \%$ \\
\hline
\end{tabular}


Table 5. Percent of Evaluation Content $(\mathrm{N}=83)$.

\begin{tabular}{|c|c|c|c|}
\hline \multirow[t]{2}{*}{ Evaluation content } & \multicolumn{2}{|c|}{ Responses } & \multirow[b]{2}{*}{ Percent of Cases } \\
\hline & $\mathrm{N}$ & Percent & \\
\hline Sport skills & 73 & $29.8 \%$ & $94.8 \%$ \\
\hline Sport knowledge & 45 & $18.4 \%$ & $58.4 \%$ \\
\hline Attitude & 71 & $29.0 \%$ & $92.2 \%$ \\
\hline Sport fitness & 54 & $22.0 \%$ & $70.1 \%$ \\
\hline Others & 2 & $0.8 \%$ & $2.6 \%$ \\
\hline Total & 245 & $100.0 \%$ & $318.2 \%$ \\
\hline
\end{tabular}

\section{Assessment}

In this study, $53.2 \%$ of teachers applied assessment criteria from general physical education for students with disabilities and $31.2 \%$ of them took a modified version of assessment criteria. There were $15.6 \%$ of teachers used assessment criteria formulated by them. Most teachers used sport skills (94.8\%), attitude (92.2\%) as evaluation contents (see Table 5). $70.1 \%$ of responses employed sport fitness for evaluating students' learning. Only $58.4 \%$ of teachers used sport knowledge as content of assessment. Other contents for assessment included extracurricular activity and class attendance through the present research findings.

\section{Discussions}

A profile of curriculum planning on inclusive elementary physical education in Hong Kong was investigated in this study, most teachers (49.4\%) used the curriculum guidance draft by themselves; IEP was not popularly applied by teachers (10.4\%), the most common teaching object $(74.0 \%)$ was for understanding and enjoying exercise and sports, teaching contents such as basketball, track and field, football, game, rope skipping, volleyball, badminton, and gymnastics were popularly used, direct instruction strategy was popularly used by $72.7 \%$ of teachers, and most teachers used sport skills (94.8\%), attitude $(92.2 \%)$ as evaluation contents.

There were National Physical Education Curriculum and guiding principle for teaching students with disabilities in England. However, unlike England, there was a lack of curriculum guidance for inclusive physical education in Hong Kong. That was why most teachers (49.4\%) used curriculum guidance drafted by them when planning inclusive physical education and $40.3 \%$ of teachers used general curriculum guidance released by EDB of Hong Kong (see Figure 1).
According to our findings, the individualized Teaching Plan (IEP) was not popularly used for planning inclusive physical education (10.4\%). IEP includes many important components (e.g., determine present level of performance, determine schedules of service, and transition services) and the implementation of IEP requires the support and cooperation from multidisciplinary (Block, 2007). In Hong Kong, however, primary P.E. teachers complained that they received little support and personnel support provided for them were also very limited. That is one of the reasons why IEP is not popular in Hong Kong. On the contrary, in U.S., all students with disabilities should receive the IEP, which was written in the legal document in order to ensure high-quality education (Lieberman, \& HoustonWilson, 2002). The absent of writing IEP into legal documents is another reason that leads few teachers employed IEP in their curriculum teaching.

$36.4 \%$ of teachers chose "overcoming disabilities" as their teaching objective (see Table 2). The objective was very popular before the 1950 since the physical education for students with disabilities was more medical oriented (Jansma, \& French, 1994) and it tried to overcome disabilities through physical education. However, this objective was out of date at least in Hong Kong or some other countries (e.g., U.S.). In these countries, health-related fitness and active lifestyle became key area of physical education (Hardman, 2008). For example, the Curriculum Development Council (CDC) in Hong Kong decided that physical education should aim to help students have active and healthy lifestyles (CDC, 2002). In our findings, $64.9 \%$ of teachers selected "cultivate health and lifestyle and exercise habits" as their teaching aims (see Table 2). That means the guidance from CDC was not thoroughly implemented by teachers and thus indirectly influences students' participation of physical activity. 
Peer and collaborative teaching strategies have been shown to be an immense help for inclusive physical education. For example, peer tutoring can increase physical activity level for students with disabilities, especially when students with severe disabilities were included (Lieberman, Dunn, van der Mars, \& McCubbin, 2000; Kodish, Kulinna, Martin, Pangrazi, \& Darst, 2006). Table 4 demonstrated that peer teaching and collaborative learning strategies were applied by $44.2 \%$ and $39.0 \%$ of the teachers respectively. Factors including the student, the subject matter content to be taught, the teacher, the learning environment, and time may have impact on the selection of teaching strategies (Buck, Lund, Harrison, \& Cook, 2007). At present, Hong Kong's primary schools spend only 40-70 minutes on physical education per week (Ha, 1999). That was why peer teaching and collaborative learning strategies were not very commonly used and $72.7 \%$ of teachers used direct instruction for inclusive physical education since it provided the most efficient use of class time (Metzler, 2005). Multiple teaching strategies were used by teachers through our research finding and this was consistent with the findings by Hodge et al. (2004).

Duchane and French (1998) reported that teachers used a different grading criterion for their students with disabilities compared to their students without disabilities. Students with disabilities were graded mostly on participation, dressing, and effort, while students without disabilities were graded more on written, fitness, and skill tests. This was inconsistent with our research findings. In our study, $53.2 \%$ teachers applied same assessment criteria for both students with and without disabilities and only some of them used different grading criterion. This might dut to the CDC guided that different assessment strategies can be employed when necessary for avoid leading negative attitude or frustration to students with disabilities (CDC, 2002). Even though a flexible grading criterion was allowed for assessing students with disabilities, few teachers grade students' sport knowledge (see Table 5). Because sport knowledge was a key learning area within physical education in Hong Kong and most inclusive students have an average IQ and they can handle the assessment of sport knowledge. Thus, using of sport knowledge as evaluation content by primary teachers in Hong Kong was inadequate.

\section{Conclusions}

There was a lack of curriculum guidance for inclusive physical education in Hong Kong and thus leading to the diverse ways of curriculum planning by teachers. Curriculum guidance or principle for delivering inclusive physical education should be drafted by policy makers or EDB to guide teachers' curriculum planning. IEP was not commonly used by teachers and it was recommended IEP should be written in regulation documents and more support should be provided for teachers. Health oriented teaching objective which proposed by $\mathrm{CDC}$ and other countries was not thoroughly implemented by teachers. Teaching object of health should further emphasized and monitored by CDC and there is a need on increasing class time to promote students' health and fitness. Direct teaching strategy was popularly used by teachers, however, strategies of collaborative and peer teaching were not widely applied even they have been shown to be an immense help for inclusive physical education. Teachers should also place more value on knowledge assessment.

\section{References}

Block, M.E. (2007). A teachers' guide to including students with disabilities in general physical education (3rd ed.). Baltimore: Paul H. Brookes.

Block, M. E., \& Vogler, E. W. (1994). Inclusion in regular physical education: The research base. Journal of Physical Education, Recreation \& Dance, 65(1), 40-44.

Block, M.E., \& Zeman, R. (1996). Including students with disabilities in regular physical education: Effects on nondisabled children. Adapted Physical Activity Quarterly, 13, 38-49.

Borg, W., \& Gall, M. (1989). Educational research: An introduction. New York, U.S.: Longman.

Chamberlin, J.L. (1999). Inclusion in physical education: The student's voice. Unpublished master's thesis, The Ohio State University, Columbus, $\mathrm{OH}$. 
Chandler, J.P., \& Greene, J.L. (1995). A Statewide Survey of Adapted Physical Education Service Delivery and Teacher In-Service Training. Adapted Physical Activity Quarterly, 12, 262-274.

Chen, S., Lau, K.o., \& Jin, M. (2006). Students' attitudes toward including students with disabilities in regular PE settings in Hong Kong and TaiWan. Asian Journal of Exercise \& Sport Science, 3(1), 35-39.

Buck, M.M., Lund, J.L., Harrison, J.M., \& Cook, C.B. (2007). Instruction Strategies for secondary school physical education (6th ed.). New York, U.S.: McGraw-Hill.

Curriculum Development Council (CDC). (2002). Physical Education: Key learning area, curriculum guide (Primary 1-Secondary 3). Hong Kong, China: Education Department.

DePauw, K.P., \& Doll-Tepper, G. (2000). Toward progressive inclusion and acceptance: myth or reality? The inclusion debate and bandwagon discourse. Adapted Physical Activity Quarterly, 17(2), 135-143.

Duchane, K.M., \& French, R. (1998). Attitudes and grading practices of secondary physical educators in regular physical education. Adapted Physical Activity Quarterly, 15, 370-380.

EDB (2007). Inclusion. Retrieved from http://www.edb.gov. hk/index.aspx?nodeID=7400\&langno=2

Ha, A. S. (1999, Fall) A study of factors influencing achievement of teaching objectives among physical educators, Journal of the International Council for Health, Physical Education, Recreation, Sport and Dance, 57-63.

Hardman, K. (2008). Physical education in schools: A global perspective. Kinesiology, 40 (1), 5-28.

Hodge, S.R., Ammah, J.O., Casebolt, K.C., Lamaster, K., \& O'Sullivan, M. (2004). High school general physical education teachers' behaviors and beliefs associated with inclusion. Sport, Education and Society, 9(3), 395-419.
Jansma, P., \& Decker, J. (1990). Project LREIPE: Least restrictive environment usage in physical education. Washington, DC: United States Department of Education, Office of Special Education and Rehabilitation.

Jansma, P., \& Decker, J. (1992). An analysis of least restrictive environment placement variables in physical education. Research Quarterly for Exercise and Sport, 63(2), 171-178.

Jansma, P., \& French, R. (1994). Special physical education: physical activity, sport, and recreation. Cliffs, N.J.: Prentice-Hall.

Kodish, S., Kulinna, P.H., Martin, J., Pangrazi, R., \& Darst ,P. (2006). Determinants of physical activity in an inclusive setting. Adapted Physical Activity Quarterly, 23, 390-409.

Lieberman, L.J., Dunn, J.M., van der Mars, H., \& McCubbin, J. (2000). Peer tutors' effects on activity levels of deaf students in inclusive elementary physical education. Adapted Physical Activity Quarterly, 17, 20-39.

Lieberman, L.J., Houston-Wilson, C., \& Kozub, F.M. (2002). Perceived barriers to including students with visual impairments in general physical education. Adapted Physical Activity Quarterly, 19, 364-377.

Melograno, V.J., \& Loovis, E.M. (1991). Status of physical education for handicapped students: A comparative analysis of teachers in 1980 and 1988. Adapted Physical Activity Quarterly, 8, 28-42.

Metzler, M.W. (2005). Instructional models for physical education (2nd ed.). US: Holcomb Hathway, Inc.

Obrusnikova, I., Valkova, H., \& Block, M.E. (2003). Impact of inclusion in general physical education on students without disabilities. Adapted Physical Activity Quarterly, 20, 230-245. 
Place, K., \& Hodge, S.R. (2001). Social inclusion of students with physical disabilities in general physical education: A behavioral analysis. Adapted Physical Activity Quarterly, 18, 389-404.

Porretta, D., Kozub, F., \& Lisboa, F. (2000). Documentary analysis of survey research in adapted physical activity: 1984-1998. Adapted Physical Activity Quarterly, 17, 286-298.

Sherrill, C. (2004). Adapted physical activity, recreation, and sport: Crossdisciplinary and lifespan. New York, NY: McGraw Hill.

Sherrill, C., Heikinaro-Johansson, P., \& Slininger, D. (1994). Equal-status relationships in the gym. Journal of Physical Education, Recreation \& Dance, 65(1), 27$31,56$.

Shu, D. (1996). Current status and opinions on special physical education in Taiwan junior high schools: A survey study. (Unpublished master's thesis). The National Taiwan Normal University, Taiwan.
U.S. Department of Education (2005). Twenty-Fifth Annual Report to Congress on the Implementation of the Individuals with Disabilities Education Act. Retrieved from http://www.ed.gov/about/reports/annual/osep/2003/ index.html

Vogler, E.W., Koranda, P., \& Romance, T. (2000). Including a child with severe cerebral palsy in physical education: A case study. Adapted Physical Activity Quarterly, 17, 161-175.

\section{Correspondence:}

\section{Chunxiao 李春曉}

Graduate School, HKIEd,

10 Tai Po Lo Pin Road, Tai Po,

N.T., Hong Kong

香港, 新界, 大埔, 大埔露屏路 10 號,

香港教育學院, 研究生院

Email: cxli@ied.edu.hk 